\title{
Application of multi-method approach to assess groundwater- surface water interactions, for catchment management
}

\author{
T. Madlala, T. Kanyerere, P. Oberholster and Y. Xu
}

\begin{abstract}
Globally, the dependence of river systems to delayed discharge of subsurface water to augment flows during dry seasons is well documented. Discharge of fresh subsurface water can dilute concentrated river flow quality during reduced flow. Observed and reported results on the Berg River's declining water quantity and quality are a concern to the regions socio-economic growth and environmental integrity. Understanding the role of subsurface water discharges on the quantity and quality of receiving surface water courses can improve their management during dry periods. A case study was designed and implemented in the upper Berg River catchment in the Western Cape Province of South Africa to assess the influence of groundwater-surface water interaction on water quantity and quality. This study aimed to quantify and characterize the quality of subsurface water available in the upper catchment to improve observed declining water quality downstream. Hydrograph separation provided estimates of water fluxes during 2012-2014 low and high flow periods, while hydrochemical analysis provided insights on impacts of major land use activity in this catchment on water resources. Hydrograph separation analysis indicated that the Berg River is $37.9 \%$ dependent on subsurface water discharges annually. Dominant Na-Cl-type water indicates the quality of water from the upper Berg River is largely affected by natural processes including short residence times of aquifer water, rock-water interactions and atmospheric deposition of $\mathrm{NaCl}$ ions. These results provide insights for suggesting management options to be implemented to protect subsurface water for continued dilution and water resources management in the lower catchments.
\end{abstract}

\section{Introduction}

Groundwater and surface water (GW-SW) are in hydraulic connectivity over various physiographic environments. Understanding how these resources interact is crucial for the utilization, management and protection of water resources to enhance human activities and sustain ecological demands of water (Fetter 1994; Freeze and Cherry 1979; Levy and Xu 2011; Winter et al. 1998). Globally, the role of GW-SW interactions has been investigated to assess the importance of groundwater discharge to maintaining aquatic ecosystems (Braaten and Gates 2001; Burns et al. 2001), estimating groundwater recharge (Arnold and Allen 1999; Mau and Winter 1997), assessing the role of GW-SW in providing spawning grounds for fish types (Craig 2005; Crosbie et al. 2007; Hayashi and Rosenberry 2002) and overall, 
determining water availability during low flow periods (Ellis 2002; Ladouche et al. 2001; Yang et al. 2014; Zhou et al. 2013). Assessing GW-SW interactions is complex and requires the knowledge of a variety of influential factors including rainfall patterns, underlying geology, plant cover type and type of land use among many others. These factors not only influence the interaction between groundwater and surface water, but also water quality.

The aim of this study was to quantify GW-SW fluxes and characterize the quality of the water that would be able to improve the observed declining water quality in the middle and lower catchments of the Berg River in the Western Cape Province, South Africa. To achieve this aim, a case study was conducted from 2012 to 2014, in which a multimethod approach was applied to determine GW-SW exchanges fluxes using automated base flow separation, while the characterization of groundwater and surface water resources was conducted through hydrochemical analysis.

Studies conducted globally continue to indicate the combined use of multiple methods for assessing GW-SW interactions is most plausible due to the compensation of the spatial and temporal shortfalls of other methods (Binley et al. 2013; Cao et al. 2012; Cey et al. 1998; Fleckenstein et al. 2010; Kaandorp et al. 2018; Kakuchi et al. 2012; Kalbus et al. 2006; Petelet-Giraud et al. 2007; Yang et al. 2014).This study applied a multiple methods to assess $\mathrm{GW}-\mathrm{SW}$ interaction by estimating groundwater fluxes using the automated base flow separation, while GW-SW quality characterization was done using hydro-chemical analysis.

Self-purification of a river is the ability of a river to purify itself of contaminants by natural processes. Various processes are responsible, including the dilution of polluted surface water with influx of fresher surface water or groundwater, complex biologic and chemical processes (Unland et al. 2015; Whitehead and Lack 1982). It has been suggested that benthic stream biofilms are capable of assimilating and effectively retaining nutrients and are therefore crucial to river self-purification (Dodds 2003; Oberholster et al. 2015). These aquatic biota and streambed substrate configuration are important in the control of nutrient concentrations during low flow, where discharges from subsurface water storages dominate streamflow generation. The discharge of contaminated groundwater can have detrimental effects on river quality, while the discharge of less contaminated water than the river can improve the quality of the river (Conant et al. 2004; Hall 2013; Hobbs et al. 2008; New Jersey Department of Environmental Protection 2016; Oberholster et al. 2013; Opitz and Timms 2016).Conversely, river self-purification can occur if fresher subsurface water discharges into surface water bodies, thereby diluting concentrations in the river channel.

\section{Materials and methods \\ Study site description}

The Berg River catchment in the Western Cape of South Africa is an important source of water to the greater city of Cape Town, its surrounding towns and dependent ecosystems. 
The estimated groundwater potential yield (Table 1) for the Cape Town region is $66 \mathrm{Mm} 3 / \mathrm{a}$ and 28.3 Mm3/a for the Berg River Catchment (Meyer 2001; Parsons 2002). Major water uses include agriculture, domestic use and sustaining the environment. Many farms situated in the drier, lower parts of this catchment (Fig. 1) rely heavily on local groundwater and many along the river rely on surface water resources for irrigation (Parsons 2003; Ractliffe 2007). The $174 \mathrm{~km}^{2}$ headwater catchment is a mountainous sub-catchment (Fig. 2) of the Berg River Water Management Area $\left(\mathrm{S}_{33} .95733^{\circ}\right.$ and E19.07264 ${ }^{\circ}$. The area is bound by the Franschhoek and Groot Drakenstein mountains. A Mediterranean macro-climate exists, with warm-dry summers (November-March) and cool-wet winters (April-October). Mean annual precipitation (MAP), mean annual potential evaporation (MAPE) and mean annual runoff (MAR) of 1603, 1475 and $1015 \mathrm{~mm} / \mathrm{a}$, respectively. Areas defined by a disproportionate MAR to the geographical are of concern, constitute strategic water sources, termed High Water Yielding Areas (Nel et al. 2013).

The rivers and groundwater flow above and through the Table Mountain Group (TMG) geological formations (Fig. 3). The TMG in the upper catchment is comprised mainly of the chemically inert sandstones of the Peninsula Formation and the relatively mineralized sand, silt and mudstone of the Nardow and Franschhoek Shale Formations. The oligotrophic, acidic and low salinity water in the upper catchment is characteristic of TMG formation water. This highly fractured formation has secondary porosity creating conduits for water and potential contamination. Aquifers in the area are highly productive with conductivities generally less than $70 \mathrm{mS} / \mathrm{m}$ (Lasher 2011; Ractliffe 2007). Land use primarily consists of agricultural, natural vegetation cover, forestry and human settlements, with the largest proportion of land allocated to agriculture (Adams 2011; Kotzee 2010; Fig. 4 and Table 1). With these activities, understand GW-SW interactions with recognition of the reported declining surface water quality and also what role this interaction plays in remediating/diluting this contamination is important (Bugan 2008; de Villiers 2007; Jackson et al. 2013; Oberholster et al. 2015).

Table 1 Calculated area and percentage of area of the different Land uses/covers within the upper Berg River catchment

\begin{tabular}{lrr}
\hline Land use/cover & $\begin{array}{l}\text { Area of land use/cover } \\
\left(\mathrm{km}^{2}\right)\end{array}$ & \% land use/cover \\
\hline Agricultural (irrigated and dryland) & 30.10 & 17.31 \\
Forestry (Pine spp and clear-felled) & 5.15 & 2.96 \\
Natural cover (Shrub-land and low Fynbos) & 136.24 & 78.33 \\
Urban (residential) & 1.97 & 1.13 \\
Water bodies (rivers, dams and wetlands) & 0.47 & 0.27 \\
Total area & 173.93 & 100.00 \\
\hline
\end{tabular}




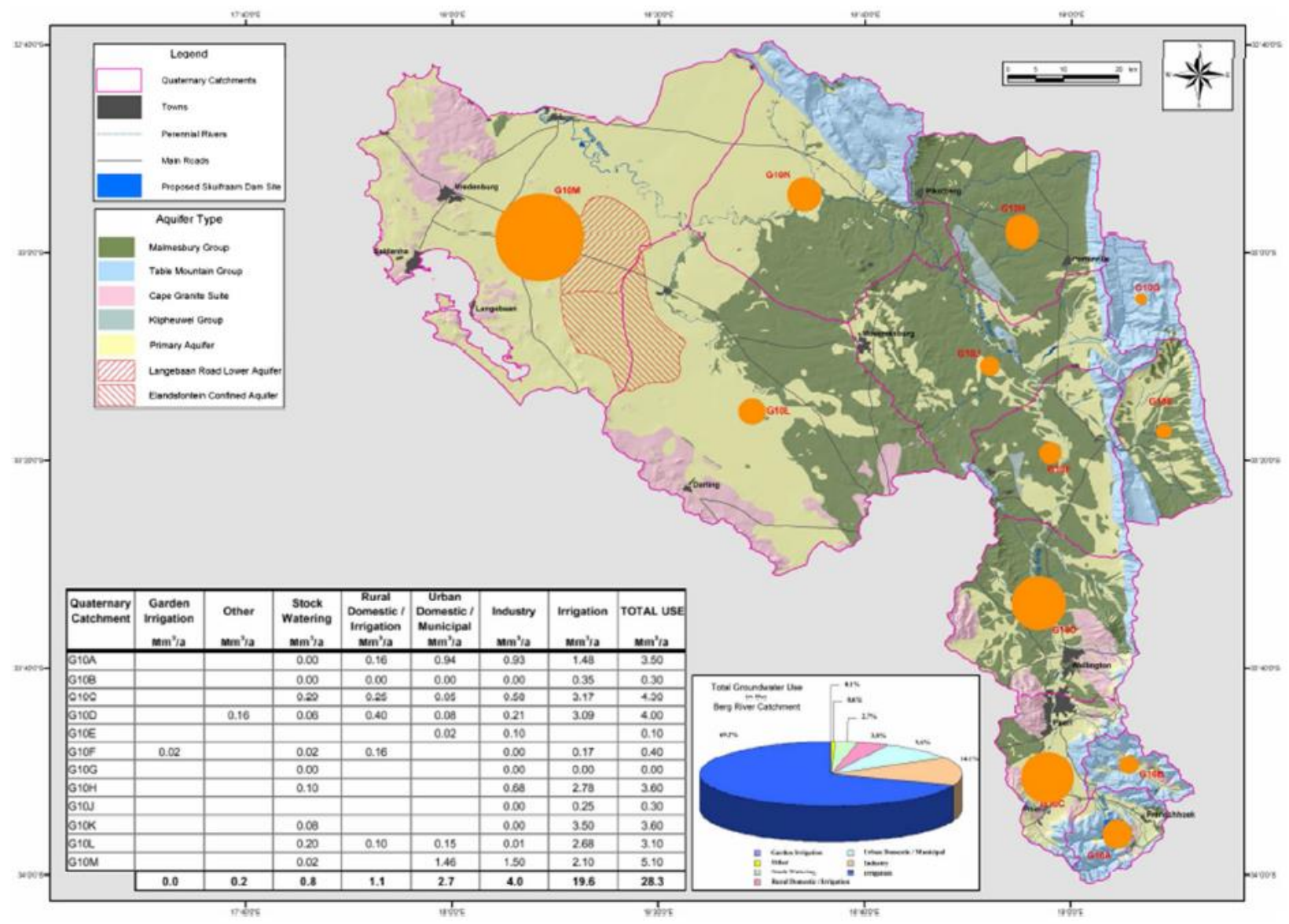

Fig. 1 Groundwater abstraction in the Berg River catchment. Source: Parsons (2003)

\section{Experimental setup}

This study used a network of 29 boreholes and 10 river sampling sites, sparsely situated in the upper Berg River catchment for the characterization of groundwater and surface water quality, as well to establish groundwater flow direction. An additional five stream gauging stations in the upper catchment were also selected for hydrograph separation to derive the quantity of groundwater discharge to surface water over time. Due to the inconsistency in stream flow data and impacts of anthropogenic activities on river flows from four of the five selected stations, station G1Ho76 situated at the BRM1 research site upstream of the Berg River Dam was selected (Fig. 4). This station exhibited no impacts of abstraction or discharge of water into or out of the stream, thereby conforming to the assumptions set by the method of quantifying groundwater discharge through the separation of a stream hydrograph into this quick and base flow components for a natural un-impacted system.

\section{Datacollectionmethods}

There are many techniques that can be considered for hydrograph separation. For continuous (filtering) separation of the different flow components, the techniques may include automated graphical methods, recursive digital filtering and use of additional data like groundwater levels (Tallaksen 1995). To separate the quick-flow and base-flow components from the stream hydrograph obtained in the upper Berg River catchment, a use of 
recursive digital filtering was made. Daily time series stream flow data spanning from September 2012 to September 2014 was retrieved from the https://www.DWA.gov.za/hydrology website (DWS 2013). This period was chosen to investigate the seasonal contributions of subsurface water storages to river flows in the upper Berg River catchment under minimal hydrological and land use/ land cover disturbances. Recession constants ( $\alpha$ parameter) of the filter algorithms from studies conducted in fractured rock environments in semiarid catchments globally were consulted to ascertain the most appropriate to use in this study (Brodie and Hostetler 2005; Hughes et al. 2003; Mau and Winter 1997; Welderufael and Woyessa 2010).

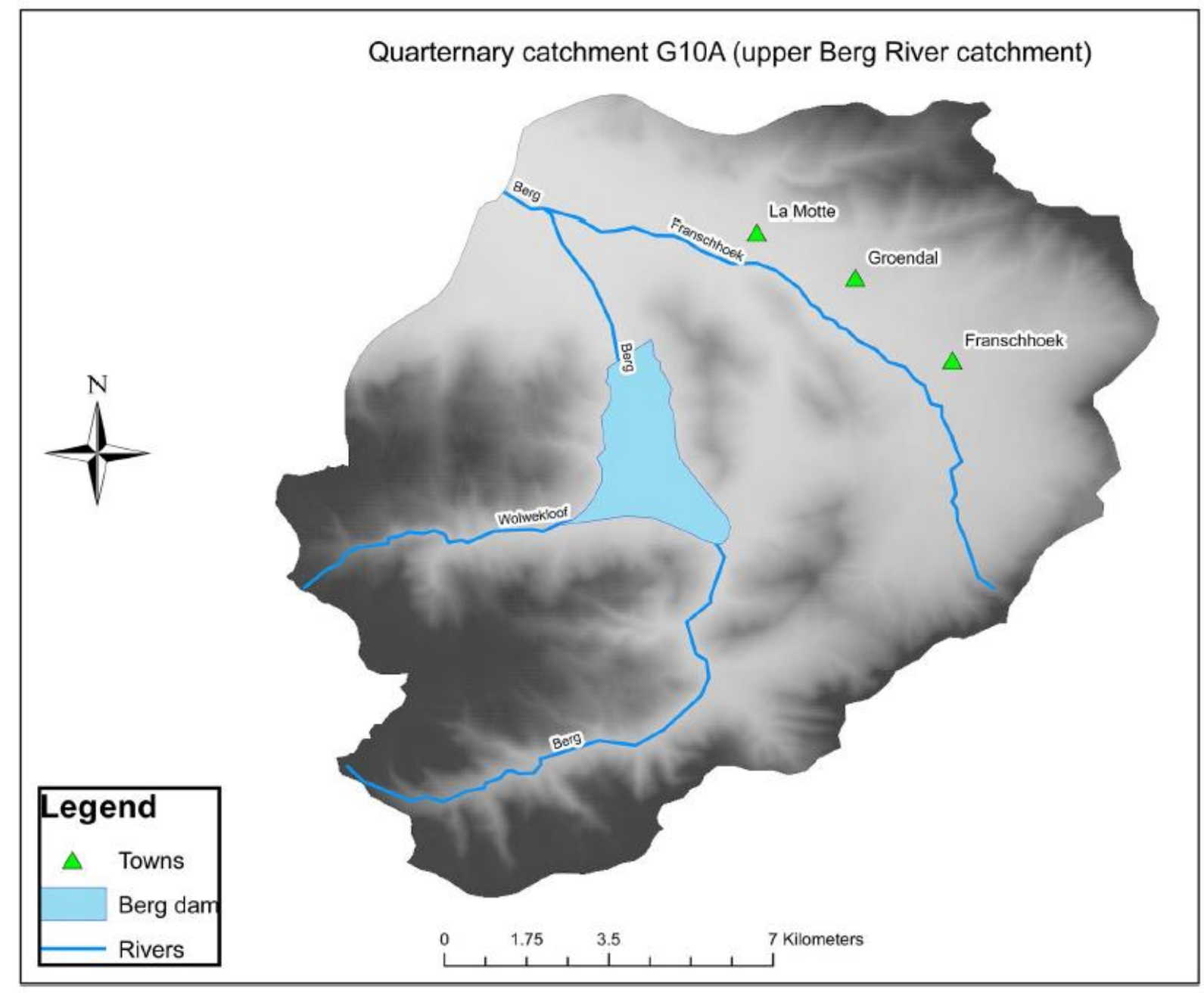

Fig. 2 Geographical location of upper Berg River catchment in relation to Western Cape Province of South Africa

As a general rule, the filter parameter $\alpha=0.925$ is suggested as starting point for most base flow separations (Smakhtin 2001). Welderufael and Woyessa (2010) and Hughes et al. (2003) suggest the similar filter parameter value $\alpha=0.925$ for South African catchments. There are many catchments where slightly higher $\alpha$ parameter values (up to 0.997) are appropriate (Hughes et al. 2003). However, an over- or under-estimation of the $\alpha$ parameter can result in substantially increased or decreased low base flow proportions (Hughes et al. 2003). While this approach offers advantages in terms of generating smoother 
base flow response results, it also introduces a further parameter to the application of the equation. Therefore, due to the uncertainty of deriving the Base flow Index (BFI) value from streamflow measurements (Eckhardt 2012) following the suggested recession coefficient parameter $(\alpha=0.925)$ was considered appropriate for this investigation of the base flow contribution to streamflow within a South African catchment.

Finally the selection and application of the Lynne and Hollick Algorithm (Nathan and McMahon 1990) along with the Chapman Algorithm (Chapman 1999; Mau and Winter 1997) were selected on the merit of their objectivity regarding the estimation of the quantity of groundwater discharge to streams. Applying the Elasticity Index (sensitivity analysis) described by (Eckhardt 2012) to the above-mentioned algorithms, the suitability of the chosen $\alpha$ recession coefficient (i.e., $\alpha=0.925$ ) was tested. Sensitivity of this recession coefficient was computed to $\mathrm{S}(\mathrm{BFI} / \mathrm{a})=0.64$ for the Chapman Algorithm, which signifies that a relative error of $\mathrm{X}$ percent in $\alpha$ parameter estimation causes a relative error of 0.64 times X percent in BFI. For the Lynne and Hollick Algorithm the sensitivity of this recession coefficient was computed to $\mathrm{S}(\mathrm{BFI} / \mathrm{a})=0.00$, indicating a lower relative error of the recession coefficient $(\alpha=0.925)$.

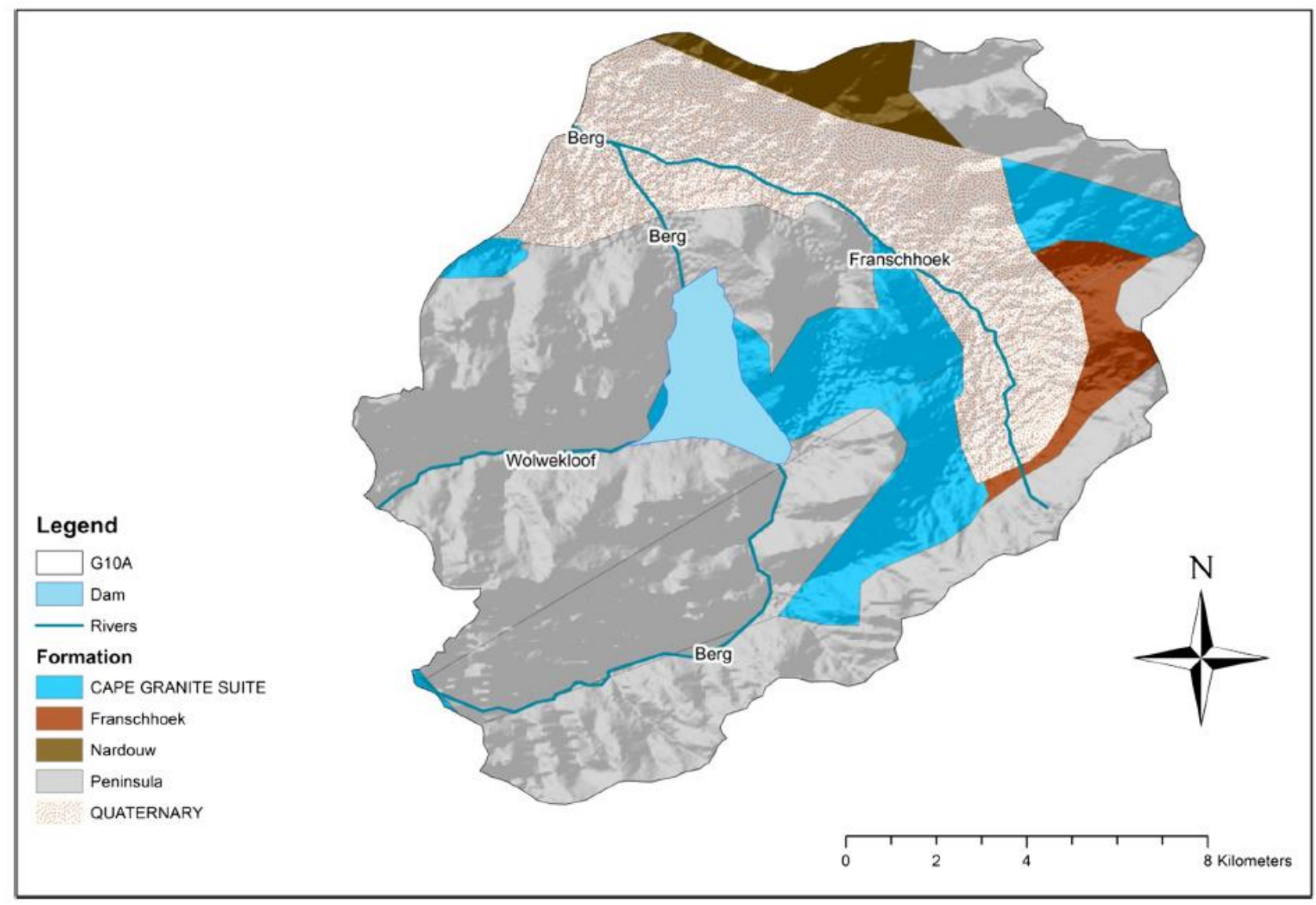

Fig. 3 Major geological formations in the upper Berg River catchment 
Time series rainfall data measured at Assegaaibos rain gauge station was retrieved from the https://www.DWA. gov.za/hydrology website and used to compare with base flow separation hydrographs (DWS 2013).

Field water quality parameters were measured with an YSI Professional Plus ${ }^{\mathrm{TM}}$ Multiparameter meter. Field measurements of electrical conductivity (EC) and total dissolved solids (TDS) were taken at all 10 river sampling sites along the Franschhoek, Berg, Stiebeuel, Wolvekloof and Roberts Rivers as well as at the 29 selected boreholes. Along with groundwater and surface water field measurements, samples were also collected for the analysis of major and minor ions dissolved in the groundwater and surface water. Duplicate grab sampling of groundwater and surface water samples was done with a grab sampler/ bailer using acid washed $250 \mathrm{ml}$ polyethylene bottles. Prior to groundwater and surface water sampling, the bottles were rinsed three times with the water that was to be sampled, and then the water sample was collected and stored in a cooler box at $4{ }^{\circ} \mathrm{C}$ to prevent any alteration of the chemical properties of the water (Department of Water 2009).

For the sampling of groundwater, where the rope attached to the bailer was insufficient, a submersible pump was inserted into the well. Thereafter the required three borehole volumes to be removed were calculated with the formula according to (Triplett et al. 2006):

\section{Purge volume $=3 \pi \cdot r^{2} \cdot h$}

where $r$ is the radius of the well under investigation and $h$ is the length of the borehole. By setting the pump to pump at $6 l / \mathrm{s}$, it became apparent that a time frame of approximately 15 min was required for the sufficient well volumes to be removed. This exercise served to remove the stagnant water that had been in the well casing so as to attain a sample representative of the general aquifer water characteristics.

\section{Data analysis methods Base flow separation}

The daily time series stream flow data retrieved from the https://www.DWA.gov.za/hydrology website was processed on Microsoft Excel ${ }^{\mathrm{TM}}$. 


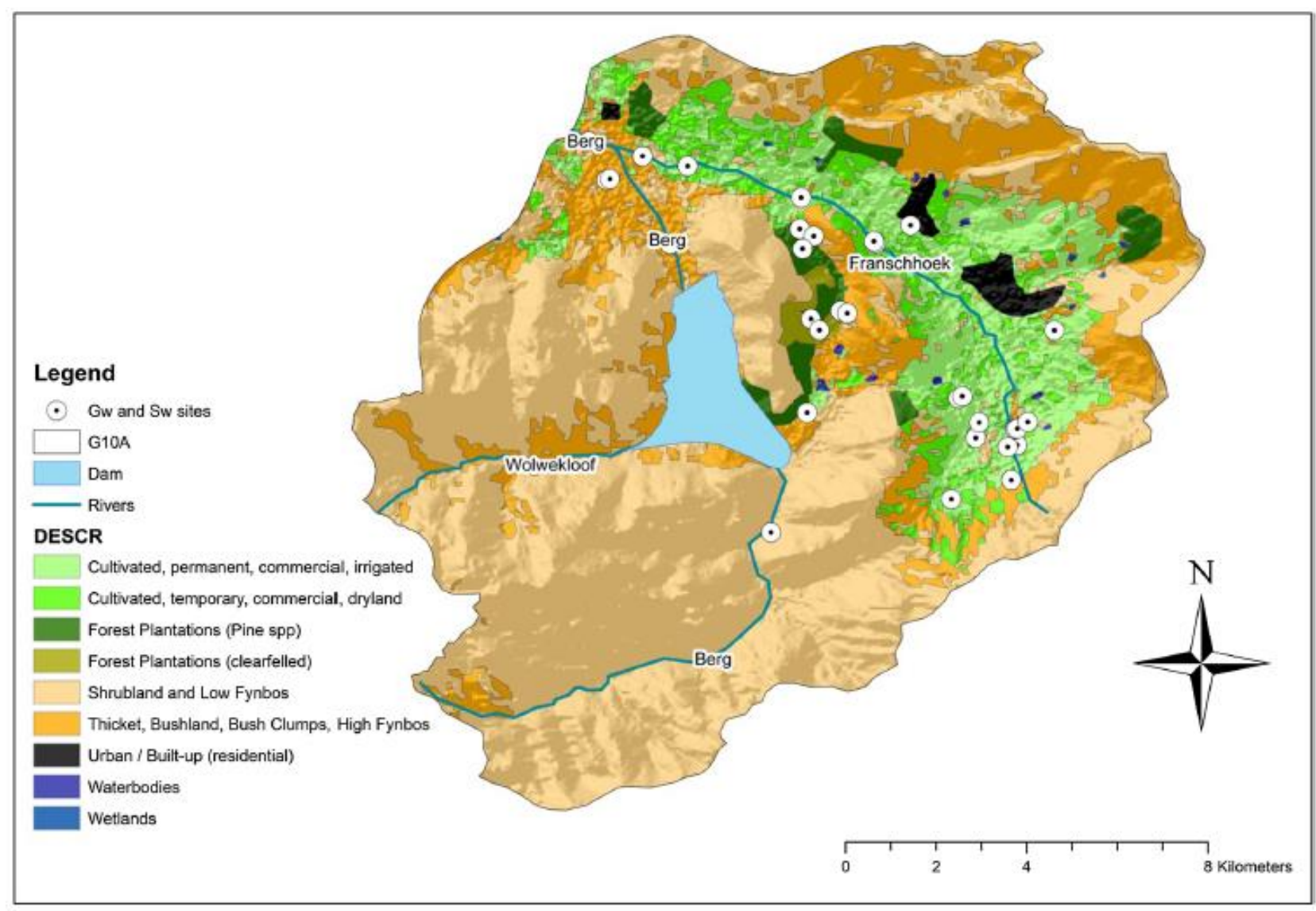

Fig. 4 Major land use in the upper Berg River catchment

To this end, the data were arranged and labeled accordingly to achieve the automated separation using automated recursive digital filters with the least possibility of errors in calculations. Recursive digital filters have no hydrological basis, but aim at generating objective, repeatable and an easily automated index that can be related to the base flow response of a stream, i.e., the Base Flow Index (BFI).

This approach provides an appropriate methodology to assess the influence of the lowfrequency component flows on total gauged runoff by removing a high-frequency component (event runoff) from a streamflow time series to determine the low-frequency component (base flow) (Eckhardt and Arnold 2001, Eckhardt 2005). Recursive digital filters selected for the separation of the base flow and direct runoff components of a stream flow hydrograph included the filter algorithms proposed by Lynne and Hollick (1979) and the Chapman (1991).

The $\alpha$ filter parameter of 0.925 was used in all Algorithms (Eqs. 2, 3 and 4). This method constituted an attempt at separating the daily time-step stream flow data. After the review of local literature that incorporated the use of these digital filters, it became apparent that filter parameter of 0.995 was more appropriate in a South African context (Hughes et al. 2003; Welderufael and Woyessa 2010). Contrariwise, Smakhtin and Watkins (1997) determined that fixed value of 0.995 for $\alpha$ filter parameter could be considered 
suitable within the South African context. Their study investigated few time series of stream flows and it was concluded that slightly higher values (up to 0.997) could be more appropriate. Due to such uncertainty within the reviewed literature, the starting value of 0.925 was utilized in this study to assess the appropriateness of such a value and provide a basis for providing a future recommendation for further investigation on the most appropriate $\alpha$ filter parameter for the upper Berg River catchment and similar catchments. This was based on the fact that Smakhtin and Watkins (1997). (Hughes et al. 2003; Smakhtin and Watkins 1997, and Welderufael and Woyessa 2010) all report that changes in $\alpha$ filter parameter from 0.925 to 0.997 have small differences between them.

The recursive digital filters proposed by Lynne and Hollick (Eq. 2) and by Chapman (Eq. 3) were used for the base flow separation procedure (Brodie and Hostetler 2005; Chapman 1991; Chapman and Maxwell 1996; Hughes et al. 2003; Nathan and McMahon 1990; Smakhtin 2001). The filter algorithms proposed are as follows:

$$
\begin{aligned}
& \mathrm{Qf}(i)=\alpha q f(i-1)+(q(i)-q(i-1))(1+\alpha) / 2 \\
& \mathrm{Qf}(i)=(3 \alpha-1) /(3-\alpha) q f(i-1)+2 /(3-\alpha)(q(i)-\alpha q(i-1) \\
& \mathrm{QB}(i)=Q(i)-q f(i) \\
& \mathrm{BFI} \%=Q b(i) / q f(i)
\end{aligned}
$$

where $q f_{(i)}$ is the filtered quick-flow component for the ith sampling period, $q f(i-1)$ is the filtered quick flow for the previous sampling period to $i, q_{(i-1)}$ is the original stream flow for the previous sampling period to $i$ and $\alpha$ is the filter parameter, and Qb(i) (Eq. 4) is the filtered base flow at the $i$ th sampling period. These digital filters have no hydrologic basis and have been borrowed from signal analysis to separate the high-frequency quick-flow signal to derive the low-frequency base flow signal as prescribed by Nathan and McMahon (1990). The Base Flow Index (Eq. 5) was calculated as ratio of base flow to total flow (Brodie and Hostetler 2005).

Groundwater and surface water field water quality parameter data were processed on Microsoft Excel $^{\mathrm{TM}}$ and presented in tabular format (Table 2), while the concentration range of nitrate-N was spatially presented on a map (Fig. 11). Field water quality data were measured with the YSI Professional Plus ${ }^{\mathrm{TM}}$ Multi-parameter meter onsite, while water samples for chemical analysis were collected thereafter for major and minor ion analysis. The collected groundwater and surface water samples were analyzed for major and minor ions using the standard methods, Inductively Coupled Plasma spectroscopy (ICP-OES, MS or AS) according to the American Public Health Association methods (APHA 1992). These methods have been widely utilized for the identification of the major ions, i.e., $\mathrm{Cl}^{-}, \mathrm{NO}_{2}{ }^{-}$, $\mathrm{SO}_{4}{ }^{-}, \mathrm{HCO}_{3}{ }^{-}, \mathrm{Na}^{+}, \mathrm{Mg}^{2+}, \mathrm{K}^{+}$and $\mathrm{Ca}^{2+}$ among others (Weight 2008). The laboratories chosen both conform to the South African National Accreditation System (SANAS), 
influencing their choice. Results on groundwater and surface water types were presented in graphical (Piper diagrams showing the water types and a map showing the ranges of nutrient concentrations). The concentrations obtained from the laboratory analysis were used to characterize the water type in the catchment as well as to infer any nutrient enrichment occurring as a result of anthropogenic activity (i.e., $\mathrm{NO}_{3}{ }^{-}$).

\section{Results and discussion}

\section{Hydrological conceptual model}

Figure $5 \mathrm{a}, \mathrm{b}$ shows the hydrological conceptual models of the upper Berg River catchment. This diagram indicates that, locally, the flow of water generally follows the topography, with shallow groundwater water levels observed in the valleys that generate the source of the perennial streams in the areas. Identification for the construction of the Berg River Dam was planned to optimally utilize this condition in the upper catchment by capturing the large runoff generated in the south-west of the catchment (Ractliffe 2007). This area is mountainous and is protected as part of the catchment area of the Berg River Dam, therefore human activities are prohibited in this area that have the potential to change the quality and decrease the quantity of runoff from this area.

Fig. 5 a Surface topography of the upper Berg River catchment, and $\mathbf{b}$ a generalized catchment conceptual model depicting the zones of recharge and discharge
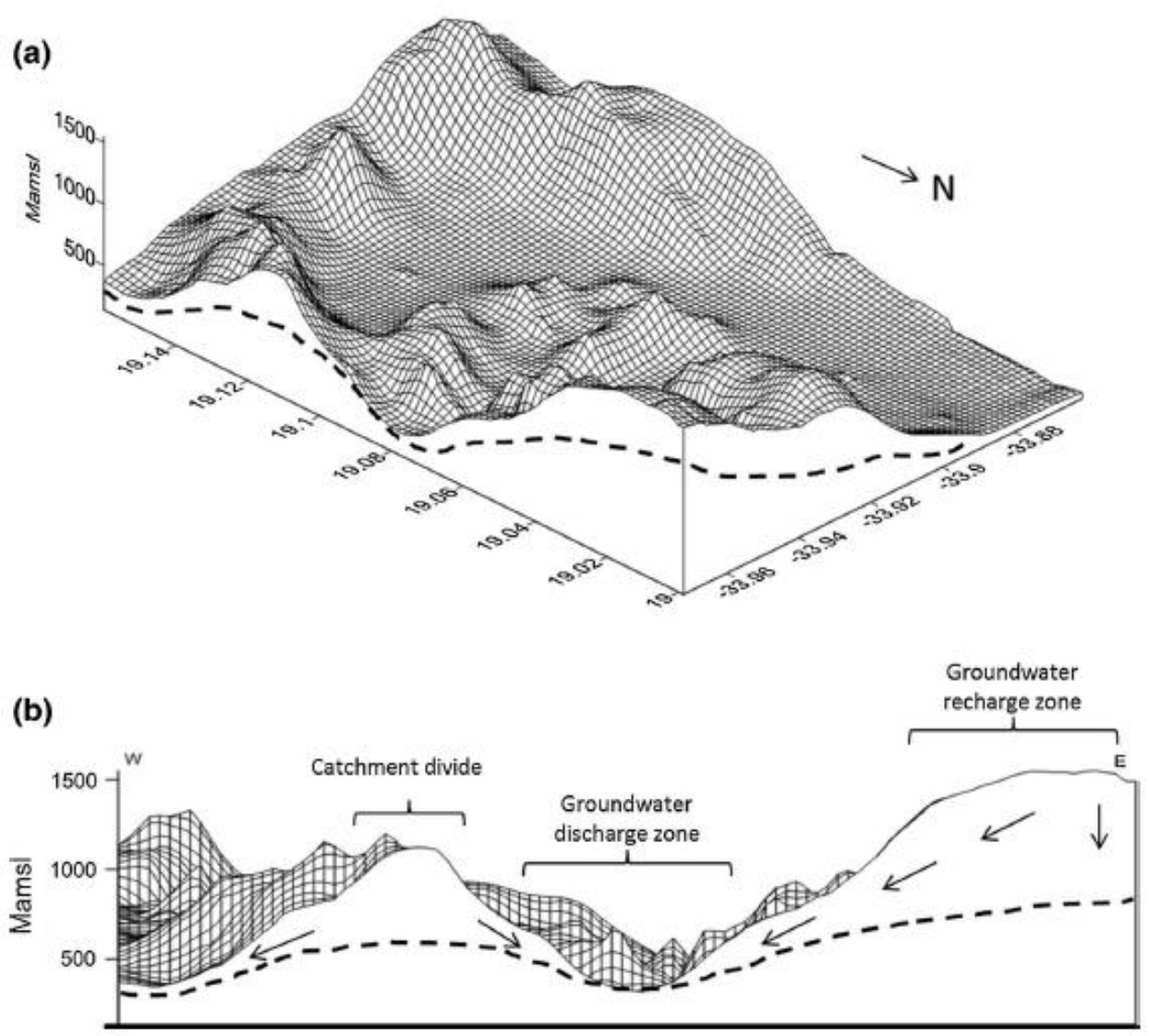

Groundwater and surface water interactions vary along the topography. In mountainous areas, the flow of ground-water is determined by the topographical conditions in the area and differences in water levels between groundwater and surface water bodies. Locally in the upper Berg River catchment, water moves downslope along the topographical gradient to 
the valleys where it discharges as base flow in the streams, wetlands, and dams. Figure 6 shows the ground-water level map for 2014. Groundwater levels were deepest near the Berg River dam (in the mountains), while the groundwater levels gradually became shallow with distance downstream. The upper mountainous parts of the upper Berg River catchment constitute a significant regional groundwater recharge area. Freeze and Cherry (1979), highlight that near the surface of groundwater recharge areas, the flow of water is directed downward (along the surface topography), while in a discharge area the flow of water is directed upward (due to intercepting surface and water levels).

\section{Base flow separation}

Figure 7 shows the daily rainfall recorded at the Assegaaibos rain gauging station between September 2012 and September 2014. From this hyetograph, it is evident that the upper Berg River catchment indeed experiences the wet winter season during the months AprilOctober with the dry season occurring between October and March. Occasional rainfall events occurred during the dry periods due to the mountainous nature of this catchment having an orographic influence to the rainfall patterns. The highest recorded daily rainfall of $180 \mathrm{~mm} /$ day was experienced in August 2013, with August 2013 also having the highest mean monthly rainfall of $791.1 \mathrm{~mm} / \mathrm{m}$. The pattern of rainfall increases as the winter months proceed and decreases to nearly no rainfall during the dry periods, with occasional sporadic rainfall events. These rainfall events further emphasize the importance of understanding how groundwater and surface water interact to prepare water management and utilization strategies that take into consideration the spatial and temporal variations in rainfall. Figures 8, 9 and 10 show that the Berg Rivers' response to rainfall events can be expected to mimic the hyetograph with minor time lags between the peaks of the hydrograph (high flow) and hyetographs (high rainfall). 
Fig. 6 G10A water level contour map
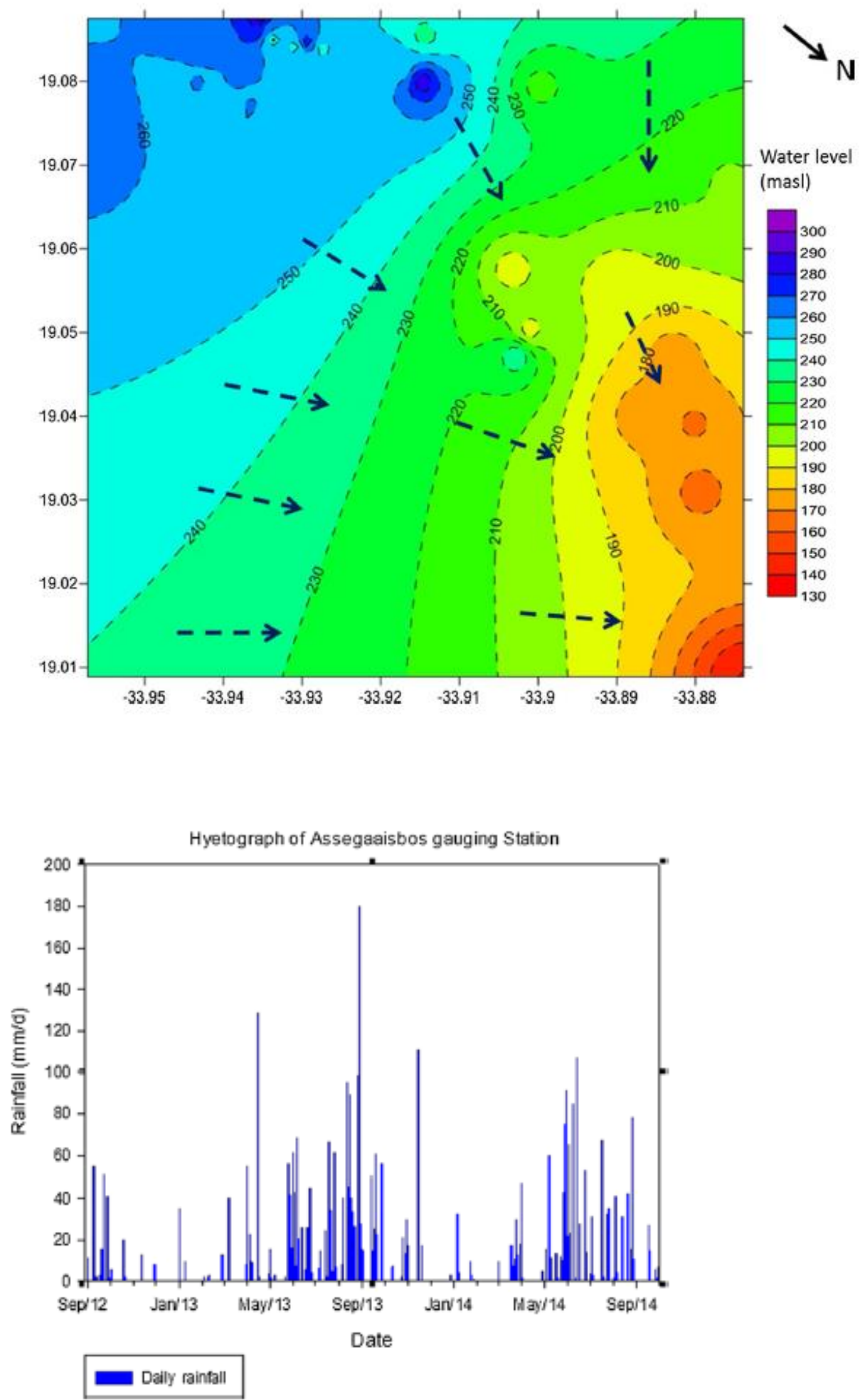

Fig. 7 Hyetograph showing rainfall measured at Assegaaibos gauging station between 2012 and 2014 (G10A-upper Berg River catchment) 


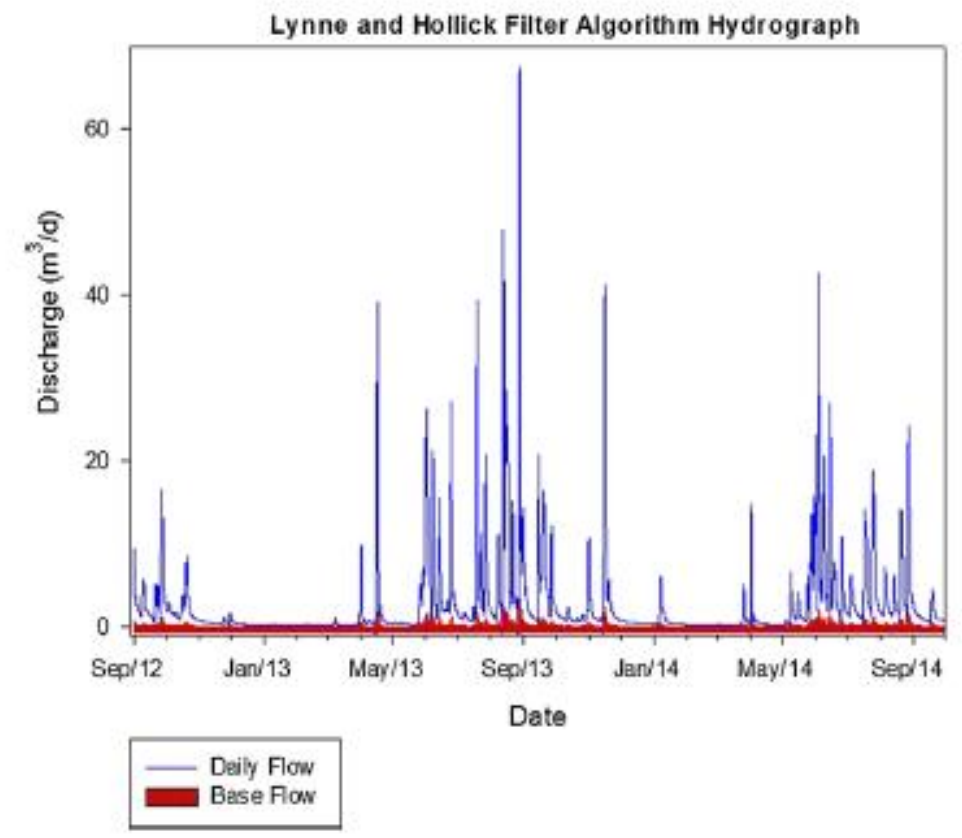

Fig. 8 Flow hydrograph of the upper Berg River (G1H076) separated to daily flow versus Base Flow using the Lynne and Hollick base flow filter algorithm

The hydrograph peaks follow shortly after the peak rainfall. Figures 8, 9 and 10 present the base flow hydrographs separated with the Chapman and the Lynne and Hollick, filter algorithms (Chapman and Maxwell 1996; Lyne and Hollick 1979; Nathan and McMahon 1990), relative to the direct runoff component of the hydrograph. 


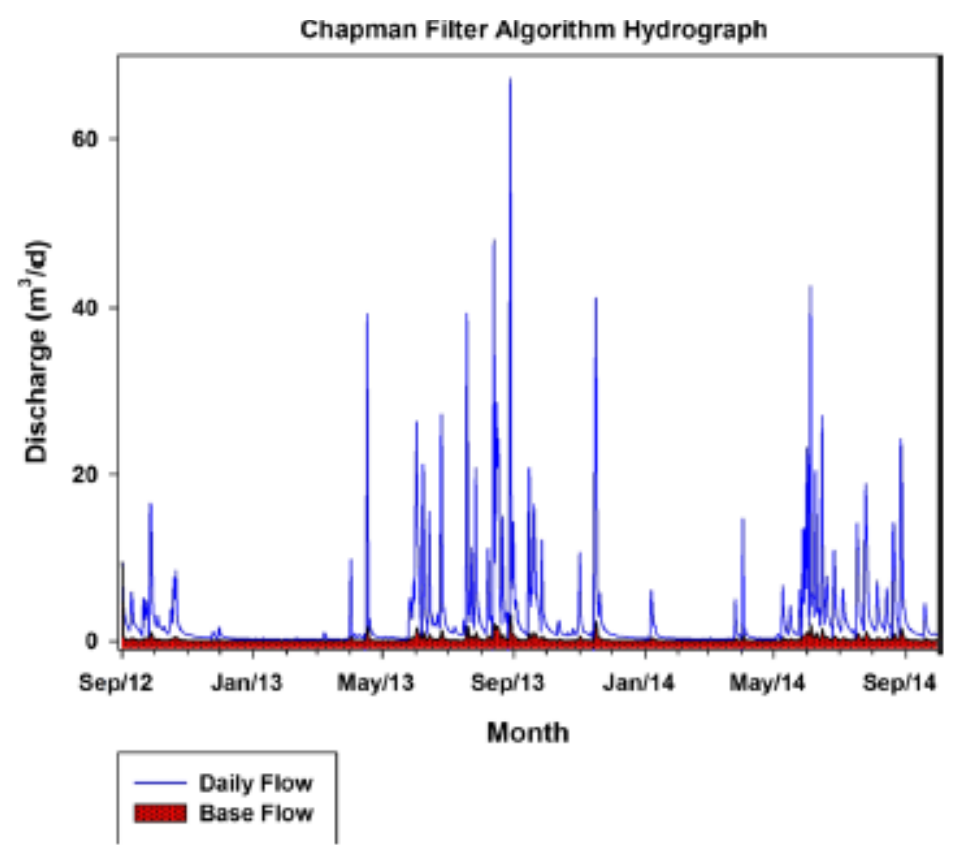

Fig. 9 Flow hydrograph of the upper Berg River (G1H076) separated to daily flow versus base flow using the Chapman base flow filter algorithm

The hydro-graphs maintain similar shapes with respect to the distribution of base flow contribution to stream flow over the hydrologic year, indicating that they all compute a relatively similar base flow contribution from subsurface water storages. Filtered base flow signals indicate a trend of declining stream flow during periods of extended dry weather (November-March), with rapid responses during the rainy periods following rainfall events (April-October). During the rainy season, the base flow discharges are more likely to be mainly interflow fed, rather than groundwater fed as this is the primary groundwater recharge period and mountain seeps along the valley could provide this flow of water. However, further investigation is recommended to identify the exact source of water contributing to stream flows during this period. The two algorithms (Chapman and Lynne and Hollick) computed similar base flow contributions. The mean, standard deviation, maximum and sum of base flow contributions (Table 3) filtered by the two algorithms were 0.214 and $0.203 \mathrm{~m}^{3} /$ day (mean), 0.354 and $0.323 \mathrm{~m}^{3} /$ day (standard deviation), 3.186 and $2.454 \mathrm{~m} 3 /$ day (Maximum) and 150.108 and $79.992 \mathrm{~m} 3 /$ day (Sum), respectively. From the descriptive statistics, there is a difference of $0.11 \mathrm{~m}^{3} /$ day in mean base flow between the two algorithms. However, considering the shape of the base flow hydrographs, both algorithms modeled similar base flow contribution from subsurface water storages within the period assessed. The Base Flow Index, which is the percentage ratio between the filtered base flow and the measured discharge at the gauging station (G1Ho76), is presented in Table 3. This information reveals that on average, the Berg River in the upper reaches is between 7.8 and $8.1 \%$ for the Chapman and Lynne and Hollick filter algorithms, respectively. Therefore, approximately $8 \%$ of river flows are derived from discharges from subsurface water storages. Although this is relatively small ratio, 
during periods of dry weather, this discharge is crucial to maintaining stream functions and flow.

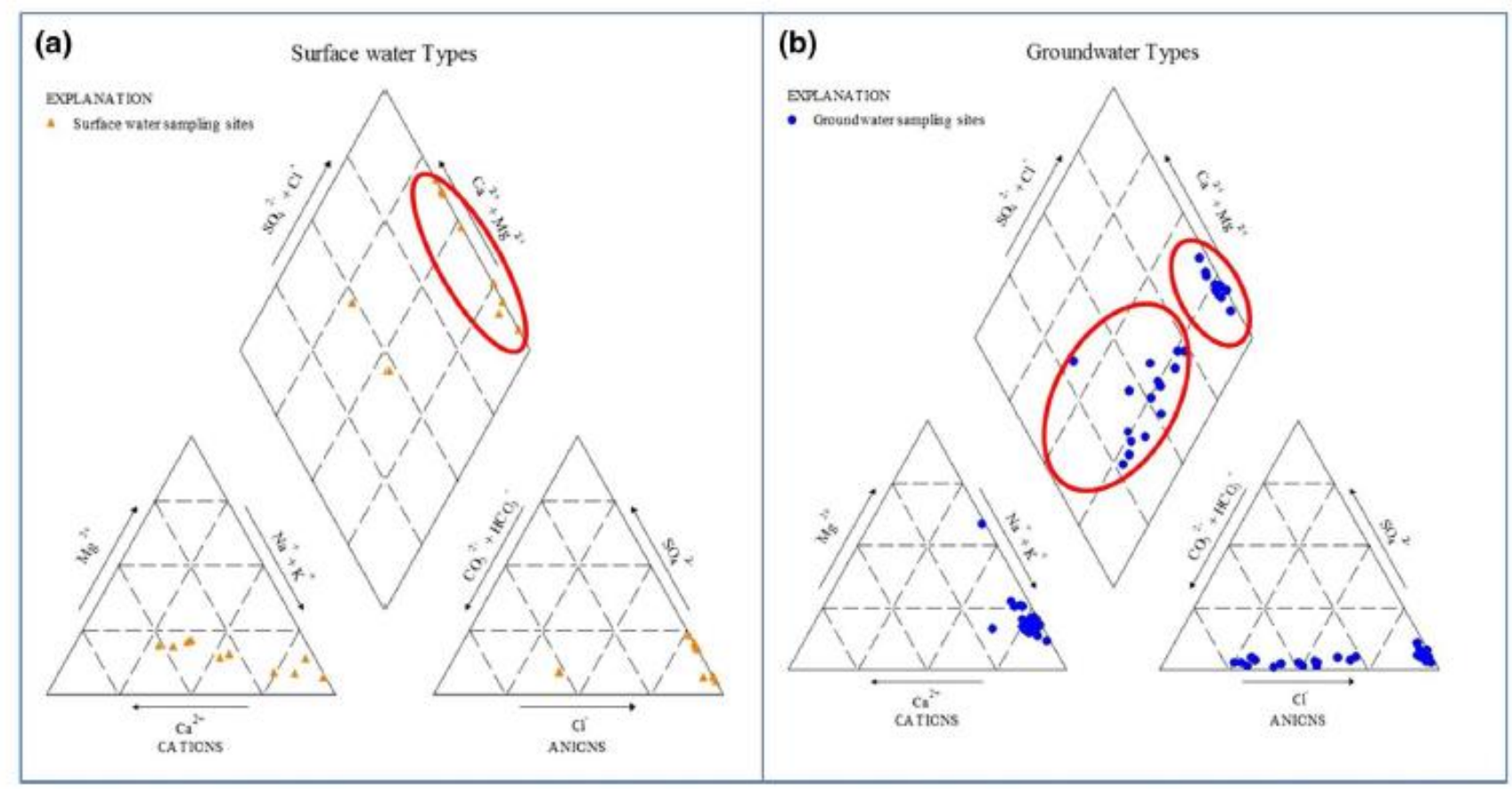

Fig. 10 Water types of a surface water and b groundwater in upper Berg River catchment

Table 3 Table listing the different water types found in groundwater and surface water in the upper Berg River catchment

\begin{tabular}{lcc}
\hline G1H076 descriptive statistics & Chapman & Lyne and Hollick \\
\hline Mean & 0.214 & 0.203 \\
SD & 0.354 & 0.323 \\
Maximum & 3.186 & 2.454 \\
Sum & 150.108 & 79.992 \\
\hline GlH076 BFI descriptive statistics & Chapman BFI & Lyne and Hollick \\
\hline Mean & & BFI \\
Maximum & 0.078 & 0.081 \\
Sum & 0.233 & 0.242 \\
\hline
\end{tabular}

The Chapman and Eckhardt algorithms modeled an identical annual mean percentage of discharge (Base flow Index) of $7.81 \%$ from subsurface drainage to the river compared to the Lynne and Hollick algorithm, which modeled an annual mean BFI of 8.1\%. The Lynne and Hollick base flow filter algorithm modeled a 30\% higher mean annual base flow (BFI) contribution to total stream flows than the Chapman filter algorithm. Considering the differences in maximum base flow contributions modeled using the two filter algorithms, the Chapman filter algorithm had a $87 \%$ higher maximum base flow value of $3.186 \mathrm{~m}^{3} / \mathrm{s}$ than the $2.454 \mathrm{~m} 3 / \mathrm{s}$ modeled by the Lynne and Hollick filter algorithm. 
The upper catchment is bound by steep mountains that affect the spatial rainfall pattern in the area, by occasionally bringing rainfall during regionally dry periods (Clark and Ractliffe 2007), which reflect on the stream flow hydrograph. The base flows filtered with the various algorithms indicate that the upper stretch of the Berg River in this area relies on the discharge of subsurface water during periods of extended dry weather (November-March). The dependency of the river to subsurface water (groundwater and interflow) discharges during wet weather gradually becomes insignificant when compared to measured total flow, as the catchment area and its streams respond almost immediately to rainfall events. This factor is further exasperated by the presence of mountain face seeps (interflow) which flow though faults and fracture conduits in the underlying aquifer. Annual mean Base Flow Indices ranging between 7.81 and $8.1 \%$ indicated a relatively significant contribution of flow from subsurface storages (i.e., groundwater and interflows) during the dry season, compared to the insignificant contribution from subsurface water storages during the rainy season. The Chapman filter algorithm maintained the highest maximum base flow contribution of $3.186 \mathrm{~m} 3 /$ day (Table 3) in August 2013.

\section{Hydrochemical analysis}

Water type

The chemistry of groundwater and surface water in a natural catchment is primarily influenced by the various type of geology through which it flows, rainfall chemistry and the land use activities occurring on the land surface. Water in contact with soluble rocks produces water with the chemical signature of the rocks. This occurs as the water weathers and dissolves the rock material (Younger 2007). However, there may be other external influences to this chemistry arising from a range of unnatural anthropogenic activities which transport chemicals into these resources. In high water yielding mountain catchments like the upper Berg River catchment, increased levels and type of anthropogenic activity pose a threat and may hinder the provision of sufficient amounts of water of usable quality to the various water users in the catchment. To understand the dominant factors contributing to groundwater and surface water quality, it is important to understand the levels of salinity in relation to the various kinds of salts dissolved (major cations and anions) in this water. In situ measurements of groundwater electrical conductivity (EC) and total dissolved solid (TDS) content revealed that the upper catchment contains relatively low content of dissolved solutes (i.e., $24.97 \mu \mathrm{S} / \mathrm{cm}$ ) due to the chemically inert geology through which it flows (Clark and Ractliffe 2007). Groundwater and surface water types in this catchment as presented in Fig. 11. Seven groundwater types exist in the upper Berg River catchment. These include $\mathrm{Na}-\mathrm{Ca}-$ $\mathrm{HCO}_{3}-\mathrm{Cl}$ (13.79\%), Na-Cl- $\mathrm{HCO}_{3}$ (6.90\%), $\mathrm{Na}-\mathrm{Cl}$ (37.93\%), $\mathrm{Na}-\mathrm{Mg}-\mathrm{Cl}$ (6.90\%), $\mathrm{Ca}-\mathrm{Na}-\mathrm{HCO}_{3}-\mathrm{Cl}(10.34 \%) \mathrm{Mg}-\mathrm{Na}-\mathrm{HCO}_{3}-\mathrm{Cl}$, (3.45\%) and $\mathrm{Na}-\mathrm{Ca}-\mathrm{Cl}-\mathrm{HCO}_{3}$ (20.69\%). The percentages represent the proportion of the groundwater sampling sites that have these water types. Regarding surface water types, three water types were found within the upper Berg River catchment, which include $\mathrm{Na}-\mathrm{Ca}-\mathrm{HCO}_{3}-\mathrm{Cl}(20 \%), \mathrm{NaCl}(10 \%)$ and $\mathrm{Na}-\mathrm{Ca}-\mathrm{Cl}$ (70\%). 


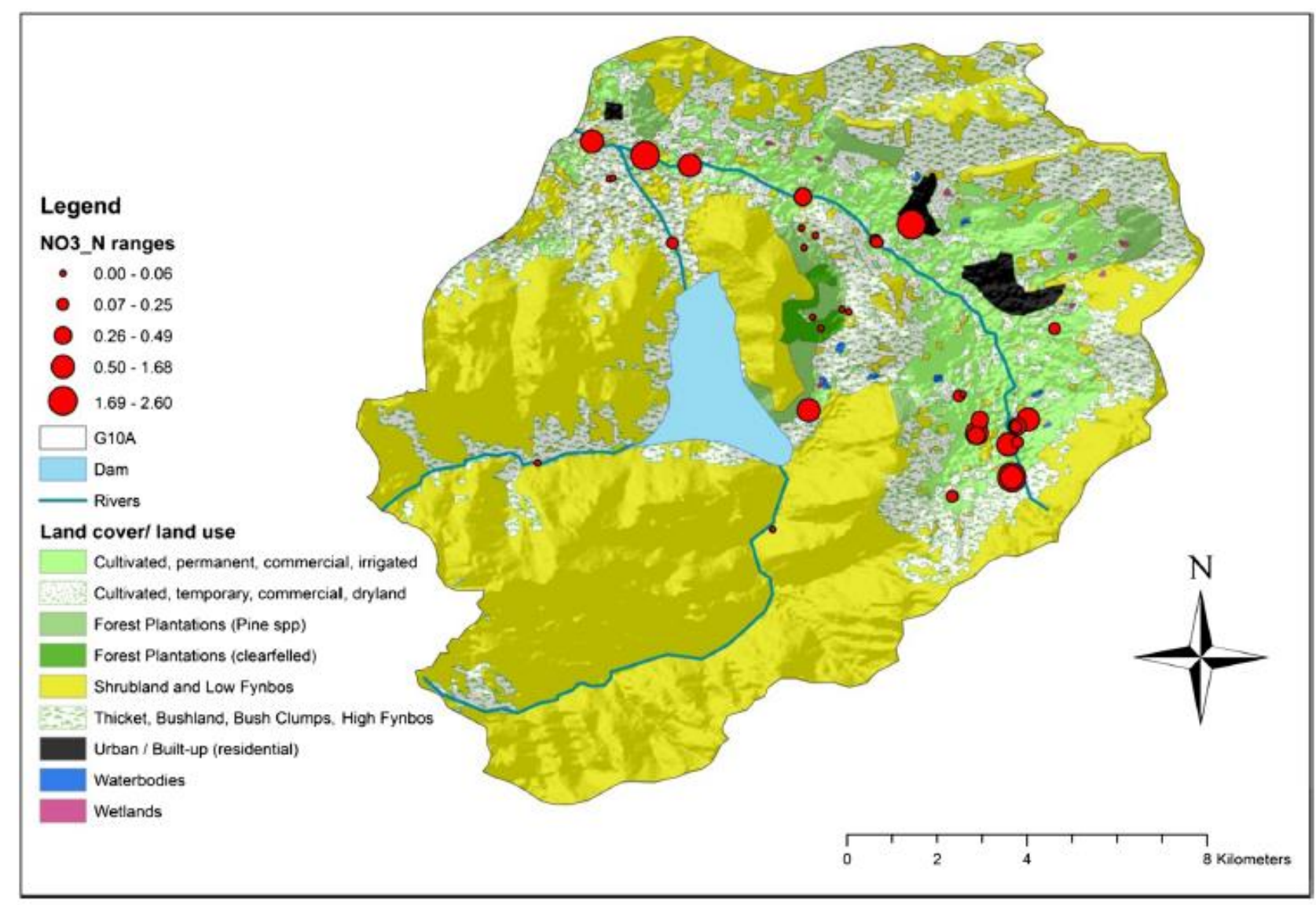

Fig. 11 Nitrate ranges in groundwater and surface water within the upper Berg River catchment

The dominance of $\mathrm{Na}-\mathrm{Cl}$-and $\mathrm{Na}-\mathrm{Ca}-\mathrm{Cl}$-type water is generally indicative of the dominance of surface water, relatively short residence times of water in the underlying aquifer, rock-water interactions, saline seeps and minor atmospheric deposition of $\mathrm{NaCl}$ ions during rainfall events (Panno et al. 2002), while the presence of $\mathrm{HCO}_{3}$ suggests microbial and bio-geochemical processes occurring at the groundwater-surface water interface.

The low salt content and mainly $\mathrm{NaCl}$ nature of the water indicate that the Berg River catchment in the upper catchment is dominated by low salt content flows through the year. These salinities increase in areas where the groundwater table was at shallow depths to the surface. In most of these areas, the activities occurring on the land surface exasperated the accumulation of dissolved solutes in the shallow groundwater and its interaction with surface water. Using multivariate statistical analysis of the principal components as well as cluster analysis, Madlala (2016) showed that groundwater and surface water were hydrochemistry and were controlled mainly by two factors, i.e., waterrock interactions $(\mathrm{Na}-\mathrm{Ca}-\mathrm{Cl})$ and the recharge of atmospherically derived $\mathrm{Na}-\mathrm{Cl}$-type water. Furthermore, three distinct clusters of groundwater and surface water we determined. These were grouped into three groups and indicated that water sampled from the Franschhoek 
agricultural are fell into one group, those sampled along the Franschhoek River fell into one group and the sites located within the Robertsvlei and Berg River Dam areas fell into on group (Madlala 2016).

\section{Nutrient concentrations}

Groundwater chemistry is influenced by a variety of natural factors as well as the activities occurring on the land surface. Where the catchment comprises an important recharge area, these external influences may have detrimental effects on the quality of groundwater. As indicated in studies by Cao et al. (2012) and Yang et al. (2012), anthropogenic inputs of chemical constituents for various reasons, such as the application of fertilizers, eventually end up influencing the chemical characteristics of the water resources. This eventuality is attributed to the fact that surface water and groundwater are in hydraulic connectivity. As pointed out by Cao et al. (2012), the infiltration of agricultural fertilizers has been detected in the local groundwater in the form of elevated nitrate concentrations. To compare to this phenomenon, this study investigated the trend of nitrate concentration ranges in the groundwater of the upper Berg River catchment and further conducted additional groundwater and surface water sampling to assess whether this observed trend is escalating or remaining constant.

Figure 11 shows the ranges of nitrate concentration ranges in groundwater and surface water sampled in the upper Berg River catchment. It is clear that areas with substantial agricultural activity (areas with bigger sized circles) have elevated concentrations of mainly agriculturally derived nitrate in the groundwater. In these areas, groundwater levels area relatively shallow, within $4 \mathrm{~m}$ below the surface were detected (Mutoti 2016). The conceptual model depicted in Fig. 6 indicates that locally, as illustrated by Toth (1963) groundwater flows along the topographical gradient and regionally then flows in a northerly direction, where interactions between groundwater and surface water are dictated by the relative elevations of the water table with respect to the surface elevation. From this Fig. 11, it can be seen that nitrate concentrations are higher in surface water and groundwater near the Franschhoek River and in areas of extensive agricultural activity or human settlement (informal), than in the lower reaches of the Berg River and areas covered by natural land cover (Fig. 11). Groundwater nitrate levels were generally below 0.05 $\mathrm{mg} / \mathrm{L}$; however, as indicated in Fig. 11, these concentrations increase in groundwater near rivers along anthropogenically utilized land, thus alluding to the relative connectivity of the surface water to the groundwater aquifers. Such revelation prompts further research into the nitrate loading and fluxes between groundwater and surface water in these areas. Since after the completion of the construction of the Berg River Dam from 2005 to 2008 and the clearing of invasive alien plants species from the Berg River Dam catchment area (Albhaisi et al. 2013; Clark and Ractliffe 2007), no catchment disturbance has been reported. Therefore, the higher nitrate concentrations seem to be originating from the anthropogenic activities, such as the agriculture, the old Franschhoek wastewater treatment works (WWTW) along the Franschhoek River and the Langrug informal settlement within the largely agriculturally driven catchment. 
These increases in nitrate concentrations are observed in boreholes located on land that is used for agricultural activity along the Franschhoek River and in the Robertsvei Saddle area (see Fig. 11). The presence of nitrate in the groundwater and surface water does not exceed the target water quality guidelines for all uses of water as set by the Department of Water Affairs (DWAF 1996). Considering that this area comprises a significant water source area, the increasing presence of nitrate in the groundwater suggests that although concentration levels were below water quality guidelines, anthropogenic inputs of nitrate were leaching to the important groundwater reserves and also affecting surface water. Further investigation is recommended to assess the nitrate capacity that the Berg River system can handle and assess this in relation to the ecological reserve to ensure sufficient quantities of water of suitable quality for ecological requirements.

The Berg River site (situated downstream of the Berg River Dam) indicated the lowest loading of nitrate, while the sites located along the Franschhoek River had the highest levels of nitrate (Fig. 11). The sites situated along the Franschhoek River are predominantly used for urban settlements. de Villiers (2007) and Jackson et al. (2013) reported that as observed in the current study, the nutrient concentrations of the Berg River increase with distance downstream. This indicates that anthropogenic activities in the study area negatively impact the water resources. It is clear that the stream reaches located along or around areas with intensive agricultural activity and human settlements were more prone to exhibiting elevated concentrations of plant nutrients derived from anthropogenic activities. Elevated nitrate levels found at the Franschhoek and Stiebeuel Rivers showed a substantial input of nitrate into the river system. Such high loading indicates the influence of the informal settlements (Langrug) and decommissioned wastewater treatment works along the Franschhoek River. Contrary to the fact that there is intensive agricultural land use activity that is contributing substantially to nitrate concentrations in surface water, the Stiebeuel River traverses through an informal settlement with poor sanitation. Nitrate is also derived from animal fecal matter, and at this informal settlement, the lack of sewage services and an overloaded old (decommissioned) wastewater treatment works exasperates this issue of nitrate deposition into water resources. However, following the convergence of the two rivers (Berg and Franschhoek), a reduction in the concentration ranges is observed (Fig. 11), where the ranges decrease from $0.50-1.68$ to $0.26-0.49$. The base flow contributions computed in this study for the area above the Berg River Dam plays a significant role in the regulation of contaminate concentration derived from the affected Franschhoek River arm of the catchment. However, quantification of the nitrate fluxes from agricultural and settlements as well as a computation of the self-purification capacity of these rivers is recommended to assess the influence that the dominant types of land uses have on water resources nitrate concentrations.

During the study period, nitrate levels in both groundwater and surface water in the upper Berg River catchment were below Department of Water and Sanitation (DWS) water quality guidelines for irrigation water. Through the application of agriculture-derived nitratecontaining fertilizers and other products for plant growth, the shallow depth to water level, migration of nitrate into groundwater through seasonal water table fluctuation is possible 
(Madlala 2016; Mutoti 2016). Groundwater in the upper Berg River catchment is partially secure from nitrate contamination in areas where the groundwater level is not close to the surface and where there are less nitrate contributing activities occurring on the land surface.

\section{Conclusion}

The current study demonstrates the applicability of base flow separation and hydrochemical analyses to assess the implications of groundwater-surface water interactions on river water quality, i.e., contamination or self-purification potential. This study shows that in the upper catchment, the Berg River is between 23 and $24 \%$ dependent on discharges from subsurface storages during extended periods of days of no rainfall. This percentage flow derived from subsurface water storages is important for maintaining water quality during these times, when there is less precipitation flushing contaminants downstream. However, during this study, the self-purification process was not studied and it is recommended that further investigation into the role that these subsurface water discharges play in the regulation of water quality during dry periods though the computation of a river self-purification potential.

The shallow depth to the groundwater table during the wet season indicates that groundwater in parts of this area is susceptible to contamination from surface land use activities when high recharge rates are reported during such periods. Groundwater and surface water in areas mainly utilized for agricultural and human purposes has indicated a connection between the presence of nutrients with the groundwater levels during the year. However, it is recommended that the influence of the declining water levels, evapotranspiration and antecedental soil moisture conditions is assessed for their influence on nutrient loading into groundwater.

The base flow separation filter parameter utilized in this study provides a good starting point for the quantification of the contributions of subsurface water discharges to total gauged streamflows. As such, conducting a hydrochemical or isotope base hydrograph separation is recommended to assess the applicability of the standard filter parameters used in this study. Additionally, assessing the sensitivity of the derived filter parameters will provide a basis for future research on the actual quantity of water derived from subsurface water storages to total gauged stream flows.

The findings of the current study indicate that there is a requirement for further investigation on the nitrate capacity of the Berg River system in handling increased concentrations of nitrate. Quantifying these fluxes from agricultural activities and human settlements is suggested to assess the influence on water resources quality that these types of land uses have. It is also recommended that research on the nutrient fluxes from surface land uses to water bodies is conducted to assess the effect of the quantity of such land use derived nutrients on the quality of groundwater and surface water. 


\section{Acknowledgements}

The authors express their sincere gratitude to the Department of Water and Sanitation officials from the Bellville office, Western Cape, Researchers from the Council for Scientific and Industrial Research, Stellenbosch, Western Cape, and staff and fellow students at the Department of Earth Science at the University of the Western Cape, for helping with the groundwater and surface water sampling and drafting of this manuscript. The authors want to thank the African Union, the Applied Center for Climate and Earth Systems Science for provision of funding. The authors would also like to express their gratitude to the unknown referees for their critical reviews of the manuscript and suggesting changes to improve the manuscript. 


\section{References}

Adams KM (2011) The inorganic pollution of the Franschhoek River: Sources and Solutions, M.Sc. Thesis, University of the Western Cape

Albhaisi M, Brendonck L, Batelaan O (2013) Predicted impacts of land use change on groundwater recharge of the upper Berg River catchment, South Africa. Water SA 39(2):211-220

American Public Health Association (APHA), American Water Works Association (AWWA), and Water Pollution Control Federation (WPCF) (1992) Standard methods for the examination of water and wastewater, 19th edn. APHA, AWWA, and WPCF, Washington

Arnold JG, Allen PM (1999) Automated methods for estimating baseflow and groundwater recharge from streamflow records. J Am Water Res Assoc 35(2):411424

Binley A, Ulla S, Heathwaite LA, Heppell C, Byrne P, Lansdown K, Zhang H (2013) Revealing the spatial variability of water fluxes at the groundwater-surface water interface. Water Resour Res 49:1-15

Braaten R, Gates G (2001) Groundwater-surface water interaction in inland South New Wales: a scoping study. Water Sci Technol J 48:215-224

Brodie RS, Hostetler S (2005) A review of techniques for analyzing baseflow from stream hydrographs. Managing Connected Water Resources Project, Queensland

Burns DA, McDonnell JJ, Hooper RP, Peters NE, Freer JE, Kendall C et al (2001) Quantifying contributions to storm runoff through end-member mixing analysis and hydrologic measurements at the Panola Mountain Research watershed (USA). Hydrol Processes 15:1903-1924

Bugan R (2008) Hydrosalinity fluxes in a small catchment of the Berg River, Western Cape, M.Sc. Thesis. University of the Western Cape

Cao Y, Tang C, Song X, Lin L, Zhang Y (2012) Characteristic of nitrate in major rivers and aquifers of the Sanjiang Plain, China. J Environ Monit 14:2624-2633

Cey EE, Rudolph DL, Parkin GW, Aravena R (1998) Quantifying groundwater discharge to a small perennial stream in Southern Ontario, Canada. J Hydrol 210:21-37

Chapman TG (1991) Comment on the evaluation of automated stream flow recession and base flow separation, by RJ Nathon and TA McMahon. Water Resour Res 27(1):17831784

Chapman TG (1999) A comparison of algorithms for stream flow recession and baseflow separation. Hydrogeol Process 13(5):701-714 Chapman TG, Maxwell AI (1996) Baseflow separation-a comparison of numerical methods with tracer experiments. 96/o5539-545. In: Institute of engineers national conference, Australia

Clark B, Ractliffe G (2007) Berg river baseline monitoring program, final report, volume 5 . Department of Water Affairs and Forestry, Pretoria, South Africa

Conant B, Cherry JA, Gillham RW (2004) A PCE groundwater plume discharging to a river: Influence of the streambed and near-river zone on contaminant distributions. $\mathrm{J}$ Contam Hydrol 73(1-4):249-279. https://doi.org/10.1016/j.jconhyd.2004.04.001 
Craig AL (2005) Evaluation of temporal and spatial variation of groundwater discharge to streams. MSc Thesis. The Graduate School of Clemson University, Clemson, South Carolina, USA

Crosbie R, McEwan IJ, Holland K, Lamontagne S (2007) Surface water-groundwater interactions in three River Murray floodplain wetlands: Results from field studies. CSIRO, Canberra, Australia Department of Water (2009) Surface water sampling methods and analysis-Technical appendices. Government of Western Australia Perth

Department of Water Affairs and Forestry (DWAF) (1996) South African Water Quality Guidelines. volume 4: Agricultural use: irrigation. DWAF

Department of Water Affairs and Sanitation (DWS) (2013) Department of Water Affairs and Sanitation Hydrological Services - Surface Water Home. Retrieved 07 15, 2013, from https://www.dwa.gov. za/hydrology/ DWS

Dodds WK (2003) The role of periphyton in phosphorus retention in shallow freshwater aquatic systems. J Phycol 39:840-849. https://doi.org/10.1046/j.15298817.2003.02081.x

Eckhardt K (2005) How to construct recursive digital filters for base- flow separation. Hydrol Process 19(2):507-515. https://doi. org/10.1002/hyp.5675

Eckhardt K (2012) Technical note: analytical sensitivity analysis of a two parameter recursive digital baseflow separation filter. Hydrol Earth Syst Sci 16:451-455

Eckhardt K, Arnold JG (2001) Automatic calibration of a distributed catchment model. J Hydrol 251:103-109. https://doi.org/10.1016/ So022-1694(01)00429-2

Ellis PA (2002) The impact of urban groundwater on surface water quality: Birmingham, River Thames Study, UK. PhD Thesis, The University of Birmingham, Birmingham

Fetter CW (1994) Applied hydrogeology, 3rd edn. Macmillan Collage Publishing Company, New York

Freeze AR, Cherry JA (1979) Groundwater, 1st edn. Englewood Cliffs, Prentice Hall

Fleckenstein JH, Krause S, Hannah DM, Boano F (2010) Groundwater-surface water interactions: New methods and models to improve understanding of process dynamics. Adv Water Res 33:1291-1295

Hall I (2013) The South African coal roadmap. Fossil Fuel Foundation. p 52

Hayashi M, Rosenberry D (2002) Effects of groundwater exchange on hydrology and ecology of surface water. $J$ Groundw Hydrol 40(3):309-336. https://doi.org/10.1111/j.1745-6584.2002.tbo26 59.x/pdf

Hobbs P, Oelofse SH, Rascher J (2008) Management of environmental impacts from coal mining in the upper olifants river catchment as a function of age and scale. Int $J$ Water Resour Dev 24(3):417- 431. https://doi.org/10.1080/07900620802127366

Hughes D, Hannart P, Watkins D (2003) Continuous baseflow separation from time series of daily and monthly streamflow data. Water SA 29(1):43-48

Jackson VA, Paulsen AN, Odendaal JP, Khan W (2013) Identification of point sources of metal pollution in the Berg River, Western Cape South Africa. J Water Air Soil Pollut 224:1477

Kaandorp VP, Molina-Navarro E, Andersen HE, Bloomfield JP, Kuijper MJ, De Louw PG (2018) A conceptual model for the analysis of multi-stressors in linked groundwatersurface water systems. Sci Total Environ 627:880-895 
Kakuchi CP, Ferre TP, Welker JM (2012) Spatially telescoping measurements for improved characterization of groundwater-surface water interactions. J Hydrol 446-447:1-12

Kalbus E, Reinstorf F, Schirmer M (2006) Measuring methods for groundwater-surface water interactions: a review. Hydrol Earth Syst Sci 10:873-887

Kotzee I (2010) The ecohydrology of the Franschhoek Trust Wetland: water, soils and vegetation, M.Sc. Thesis. University of the Western Cape

Ladouche B, Probst A, Viville D, Idir S, Baque D, Loubet M et al (2001) Hydrograph separation using isotopic, chemical and hydrological approaches (Stengbach catchment, France). J Hydrol 242:255-274

Lasher C (2011) Application of Fluid Electrical Conductivity Logging for fractured rock aquifer characterization at the University of the Western Cape's Franschhoek and Rawsonville Research Sites, M.Sc. Thesis. University of the Western Cape

Levy J, Xu Y (2011) Review: Groundwater management and groundwater/surface water interaction in the context of South African water policy. Hydrogeol J 20:205-226

Lyne V and Hollick M (1979) Stochastic time-variable rainfall-runoff modelling. In: Institute of engineers national conference, Aus- tralia. pp 89-93

Madlala TE (2016) Determination of groundwater-surface water interaction, upper Berg River catchment, South Africa. M.Sc. Thesis. University of the Western Cape

Mau DP, Winter TC (1997) Estimating groundwater recharge from streamflow hydrographs for a small mountain watershed in a temperate humid climate, New Hampshire, USA. Ground Water 35(2):291-304

Meyer PS (2001) An explanation of the 1:500 ooo hydrogeological map of Cape Town 3317. Department of Water Affairs and Forestry, Pretoria

Mutoti M (2016) Estimating groundwater recharge using chloride mass balance in the upper Berg River catchment, South Africa. M.Sc. Thesis. University of the Western Cape

Nathan RJ, Mcmahon TA (1990) Evaluation of automated techniques for base flow separation and recession analyses. Water Resour Res 26(7):1465-1473

Nel J, Colvin C, La Maitre D, Smith J, Haines I (2013) South Africa's strategic water sources areas. WWF South Africa, Cape Town

New Jersey Department of Environmental Protection (2016) New Jersey department of environmental protection site remediation and waste management program characterization of contaminated ground water discharge to surface water technical

guidance. http://www.nj.gov/dep/srp/guidance/srra/gw_discharge_to_sw_tech_guidance.pdf

Oberholster PJ, Genthe B, Hobbs P, Cheng PH, De Klerk AR, Botha AM (2013) An ecotoxicological screening tool to priorities acid mine drainage impacted streams for future restoration. Environ Pollut 176:244-253. https://doi.org/10.1016/j.envpol.2013.01.010

Oberholster PJ, Oberholster PF, Trutter C, Botha A (2015) Assessing river self-purification capacity downstream of WWTP's in a low-land river sub catchment using a phosphorus sensitivity index. In: Justin AD (ed) Advances in environmental research. Nova Science Publishers, New York, pp 159-182 
Opitz J, Timms W (2016) Mine water discharge quality - a review of classification frameworks. In: Drebenstedt C, Paul M (eds) Proceedings of the international mine water association, IMWA 2016.

Freiberg/Germany: MWA 2016 - Mining meets water - Conflicts and solutions, pp 17-26. https://www.imwa.info/docs/imwa_2016/IMWA2016_Opitz_58.pdf

Panno SV, Hackley KC, Greenberg S (2002) Source identification of sodium and chloride in natural waters: Preliminary results. In: Proceedings of the 12th annual research conference of the Illinois groundwater consortium. Research on agrichemicals in Illinois, groundwater status and future directions XII, Carbondale, Illinois. http://www.water-research.net/Waterlibrary/privatewell/nacl.pdf. Accessed 18 Dec 2016

Parsons R (2003) Berg River Baseline Monitoring Program, Final Report, Volume 6. Department of Water Affairs and Forestry, Pretoria, South Africa

Parsons R (2004) Surface water-groundwater interaction in a South African context. Water Research Commission, Cape Town

Petelet-Giraud E, Negrel P, Gourcy L, Schmidt C, Schirmer M (2007) Geochemical and isotopic constraints on groundwater-surface water interactions in a highly anthropized site, The Wolfen/Bit- terfeld megasite (Mulde sub-catchment, Germany). Environ Pollut J 148:707-717

Ractliffe G (2007) Berg River baseline monitoring program, final report, Volume 1: Introduction to the Berg River Catchment, groundwater and hydrology. Department of Water Affairs, Pretoria, South Africa

Smakhtin VU (2001) Estimating continuous monthly baseflow time series and their possible applications in the context of ecological reserve. Water SA 27(2):213-217

Smakhtin VY, Watkins DA (1997) Low flow estimation in South Africa. Water Research Commission Report No. 494/1/97

Tallaksen LM (1995) A review of baseflow recession analysis. J Hydrol 165(94):349-370

Toth J (1963) A theory of groundwater motion in small drainage basins in Central Alberta, Canada. J Geophys Res 67(11):4375-4388

Triplett LD, Burford P, Sielaff B, Clark RC (2006) Sampling procedures for groundwater monitoring wells. minnesota pollution control agency, State of Minnesota

UMVOTO (2002) Water Source Development and Management Plan for the Greater Hermanus Area, Overstrand Municipality - Interim Report on Drilling and Pump testing of Exploration Boreholes

Unland NP, Cartwright I, Daly E, Gilfedder BS, Atkinson AP (2015) Dynamic river groundwater exchange in the presence of a saline, semi-confined aquifer. Hydrol Process 4829(June):4817-4829. https://doi.org/10.1002/hyp.10525

Villiers De (2007) The deteriorating nutrient status of the Berg River, South Africa. Water SA 33(5):659-664

Water Research Commission (WRC) (2003) Ecological and environmental impacts of large volume groundwater abstraction in the Table Mountain Group (TMG) aquifer system: Discussion Document for Scoping Phase. WRC Project K5/1327. Published by CSIREnvironmentek, Southern Waters and Umvoto Africa. CSIR Report Number: ENV-S-C 2003-076, Stellenbosch 
Weight WD (2008) Hydrogeology field manual, 2nd edn. McGraw-Hill Companies Inc., New York

Welderufael WA, Woyessa YE (2010) Stream flow analysis and comparison of base flow separation methods: case study of the Modder River Basin in central South Africa. Eur Water 31:3-12

Whitehead PG, Lack T (1982) Dispersion and self-purification of pollutants in surface water systems: a contribution to the International hydrological programme : a report by IHP working group 6.1. Bernan Assoc. (Technical papers in hydrological). https://books.google.co.za/books?id=rHwiAQAAIAAJ

Winter TC, Harvey JW, Franke OL, Alley WM (1998) Ground water and surface water: a single resources. U.S. Geological survey circular 1139. USGS, Denver, Colorado

Xu Y, Titus R, Holness SD, Zhang J, Van Tonder GJ, Xu Y (2002) A hydrogeomorphological approach to quantification of groundwater discharge to streams in South Africa. Water SA 28(4):375-380

Yang L, Song X, Zhang Y, Han D, Zhang B, Long D (2012) Characterizing interactions between surface water and groundwater in the Jailu River basin using major ion chemistry and stable isotopes. Hydrol Earth Syst Sci 16:4265-4277

Yang Z, Zhou Y, Wenninger J, Ulenbrook S (2014) A multi-method approach to quantify groundwater-surface water interactions in the semi-arid Hailiutu River Base in, northwest China. Hydrogeol J 22:527-541

Younger PL (2007) Groundwater in the environment: an introduction, 1st edn. Blackwell Publishing, Newcastle

Zhou Y, Wenninger J, Yang Z, Yin L, Haung J, Hou L et al (2013) Groundwater-surface water interactions, vegetation dependencies and implications for water resources management in the semi-arid Hailiutu River, China- a synthesis. Hydrology Earth Systems Sciences 17:2435-2447 
Table 2 Descriptive statistics of three filter algorithms and resultant Base Flow Index computed for gauging station G1H076 in the upper Berg River catchment

\begin{tabular}{|c|c|c|c|}
\hline Source & Site & Water type & Group \# \\
\hline GW & 3 streams & $\mathrm{Na}-\mathrm{Ca}-\mathrm{HCO}_{3}-\mathrm{Cl}$ & 1 \\
\hline GW & Holden Manz BH2 & & \\
\hline GW & Holden Manz BH3 & & \\
\hline GW & Lavenir-BHl & & \\
\hline SW & G1H03 & & \\
\hline SW & Moreson & & \\
\hline $\begin{array}{l}\text { GW } \\
\text { GW }\end{array}$ & $\begin{array}{l}3 \text { Streams-Fount } \\
3 \text { Streams-Salm }\end{array}$ & $\mathrm{Na}-\mathrm{Cl}-\mathrm{HCO}_{3}$ & 2 \\
\hline GW & BG158 & $\mathrm{Na}-\mathrm{Cl}$ & 3 \\
\hline GW & BG33 & & \\
\hline GW & BG34 & & \\
\hline GW & BG35 & & \\
\hline GW & BG35.2 & & \\
\hline GW GW & BG36 BG37 & & \\
\hline GW & BG38 & & \\
\hline GW & BG46 & & \\
\hline GW & BG50 & & \\
\hline GW & RV2 & & \\
\hline SW & Stream @ BG51 & & \\
\hline SW & Berg and Franschhoek & $\mathrm{Na}-\mathrm{Ca}-\mathrm{Cl}$ & 4 \\
\hline SW & Berg River & & \\
\hline SW & Franschhoek Bridge & & \\
\hline SW & $\begin{array}{l}\text { Franschhoek upstream } \\
\text { WWTW }\end{array}$ & & \\
\hline SW & Wolvekloof & & \\
\hline SW & $\begin{array}{l}\text { Stiebeuel-WWTW conflu- } \\
\text { ence }\end{array}$ & & \\
\hline SW & Stiebeuel River & & \\
\hline GW & BG21 & $\mathrm{Na}-\mathrm{Mg}-\mathrm{Cl}$ & 5 \\
\hline GW & BG44 & & \\
\hline GW & Bordeaux & $\mathrm{Ca}-\mathrm{Na}-\mathrm{HCO} 3-\mathrm{Cl}$ & 6 \\
\hline GW & Lacombie & & \\
\hline GW & Stonybrook & & \\
\hline GW & Cape Fruit Process & $\mathrm{Mg}-\mathrm{Na}-\mathrm{HCO} 3-\mathrm{Cl}$ & 7 \\
\hline GW & Holden Manz-Produc & $\mathrm{Na}-\mathrm{Ca}-\mathrm{Cl}-\mathrm{HCO} 3$ & 8 \\
\hline GW & Lavenir-BH2 & & \\
\hline GW & Lavenir-BH3 & & \\
\hline GW & Tsherigma & & \\
\hline GW & Burgundy-BH1 & & \\
\hline GW & Burgundy-Fount & & \\
\hline
\end{tabular}

